\title{
Children Under the Age as the Victim of Sexual Crimes
}

\author{
Vience Ratna Multi Wijaya ${ }^{1 *}$ \\ ${ }^{1}$ Faculty of Law University of Trisakti, Jakarta, Indonesia
}

\begin{abstract}
Children is the next generation of a nation and state. Therefore, it is necessary for them to get special protection both physically, mentally and socially. In order to realize the fulfillment of the children's rights. Legal Protection under Article 1 Sub-Article 2 of Law Number 35 of 2014 is all activities to guarantee, protect children and their right to live, grow, develop and participate optimally in accordance with human dignity and protection from violence and discrimination. One of the violence experienced by underage children is sexual crime victims. As for the issue: How is protection given to the law of children who are the victim of sexual crime? This study is Normative and uses secondary data, and analyzed qualitatively and is descriptive with approach refers to legislation such as Law No. 35 of 2014 jo Law No. 23 of 2002, Act NO. 17 of 2016, Law No. 39 of 1997. Results of legal protection research on children under the age of victims of crime in accordance with Article 59 paragraph 2 and Article 66 of Law No. 35 of 2014, and severe criminal sanctions on Law no. 17 year 2016, while prevention there should be cooperation between all parties KPAI, Government, Family and Society.
\end{abstract}

\section{Introduction}

Every child has human rights just like adults and it is obtained since the child was born. Children are also a mandate from God the Almighty, which we must always guard because of the inherent dignity, rights and rights of children as human beings who must be upheld. Human rights are meant by children as an integration of the 1945 Constitution, Pancasila and the United Nations Convention on the Rights of the Children. Basically, the Law No. 39 of 1999, which is concerning on Human Rights, has included the rights of children. However, in its implementation requires responsibility from all parties such as; the State, Government, Regional Government, Parents and Community so there needs to be special rules that provide special protection for all children, including children as victims of criminal acts in Law No. 35 of 2024 jo Law Number 22 of 2003. Special protection efforts for children must be given since the child is still in the womb, this is in accordance with the principle of the law of children protection regulated in the Article 3.

\footnotetext{
* Corresponding author : vientjeratna@yahoo.co.id
} 
Children need special protection that is different from adults both physically and mentally. Therefore, if we compare it with adults, children cannot protect themself and they are very vulnerable for being a victim of a crime, whether it is violence or sexual crime. Broadly speaking, the impact of children becoming victims of crime, children will experience: ${ }^{(1)}$

1. They tend to be negative, aggressive and frustrated

2. Being passive and apathetic

3. Not having their own personality

4. Low self-esteem

5. Difficult to establish relationships with other individuals

Children are development assets for the successor of the nation and state. Therefore, children are objects of Indonesian development that must be maintained and developed. Regarding to the importance of children for the development of the Indonesian state, the goverment must take participation in providing legal protection for children. This is in accordance with the Article 21 of Law Number 35 in 2014 that states, Governments and Regional Governments are obliged and responsible for the fulfillment of children's rights without discrimination. In order to realize this obligation, the state guarantees that every child has the right to survive, grow and develop themselves as well as have the right to be protected from discrimination and any form of violence. This is in accordance with the Article 21 of Law Number 35 of 2014 that states, Governments and Regional Governments are obliged and responsible for the fulfillment of children's rights without any discrimination. In order to realize this obligation, the state guarantees that every child has the right to survive, grow and develop themselves as well as have the right to be protected from discrimination and any form of violence. Along with the development of the era and advances in technology, where it affects the lives of children, they prefer to sit for hours using sophisticated technology rather than establishing closeness to their family and friends. In that way the child may become addicted to negative contents, such as pornography which eventually the child affected and becomes a victim. In addition, there are families who are more concerned with careers rather than paying attention to children's development by giving up the responsibilities of parents to helpers or family / siblings, causing the relationship between parents and children are not as close as it should be. In addition, the child must not be allowed to be hugged, touched, held on a lap, kissed, even if in a family environment., but the child must be invited to communicate about sexual problems after early. Thus the child dares to reject this with the argument of affection for the child. This is one of the factors why many children are being victims of sexual crimes.

Based on the report of the National Commission for Children Protection (Komnas Anak), the Commissioner of KPAI Jasra Putra reveals that the data show his party had found 218 cases of child sexual violence in 2015. While, in 2016, KPAI noted that there were 120 cases of sexual violence against children. Then in 2017 , there were 116 cases. ${ }^{(2)}$ Therefore, there needs to be a legal rule that has a potential to provide justice for children of sexual victim as fulfilling the government's obligation to provide protection in the form of human rights for children especially preventing children from being victims of sexual crimes.

\section{Main Problems}

How the protection is given to underage law related to sexual crime victim? 


\section{Methodology}

In this study researcher uses a normative research method which is studying the protection of children who are victims of sexual crimes in accordance with the concept of legislation. ${ }^{(3)}$. Along with nature of descriptive research by looking at the law in the real sense and examining how the law works in society. While, the data used in this research is secondary data, using literature study. The data analysis is applied through qualitative methods; the data obtained is analyzed by legislation which is relating to child protection, especially the problem of sexual crime.

\section{Discussion}

\subsection{Regulation of Children Protection as Victims of Sexual Crimes}

Humans are created as social beings who interact each others. The natural process of humans through various phases such as infancy, toddlers, children and adults. The meaning of children according to the Article 1 paragraph 1 of Law No. 35 of 2014 is "someone who is not yet 18 years old, including fetus in the womb". Children as a nation shoot need to get special protection both physically, mentally, as well as socially in order to create children's welfare. It means, Children protection is "all activities to guarantee and protect children and their rights to live, grow, develop and participate optimally in accordance with human dignity and dignity and to be protected from violence and discrimination". Therefore, it is necessary to protect children from violence and discrimination. State, Government, Regional Government, Parents / Guardians, families and communities according to Article 20, Article 21 of Law No. 35 of 2014 needs to implement guarantees for the realization of the protection of children's rights.

Criminal acts of violence, especially sexual violence are very high, "Based on records of sexual crimes or rape, underage children occur throughout the country. Based on the records of sexual crimes against children under age, many are carried out by close people such as immediate families (fathers, uncles, or brothers), neighbors, schoolmates, lovers who have the intensity of interaction with victims. Even not infrequently it is also done by officials".(4)

The meaning of the word rape comes from the Latin "rapere", means "stealing, forcing, robbing or taking away". (5) Rape or sexual crime is a very cruel act or criminal act. This is because someone is forcing other people, in this is the underage children, to have sexual intercourse where the male genitalia enters the vagina. While the meaning of rape according to the Kamus Besar Bahasa Indonesia, based on "he said (etiology) can be explained:

1. Rape is stout, forced, violent, mighty

2. Raping is using violence and violating (attacking) with violence

3. Rape is an act of rape, violence, coercion and violation by force "(6)

While the meaning of rape goes to some experts are:

a. Soetandyo Wignjosoebroto, "rape is an attempt to vent sexual desire by a man against a woman in a manner that is morally and or violently applicable"(7)

b. R. Sugandi, "rape is a man who insists on a woman not his wife to have intercourse with him, with the threat of violence, which requires that male genitalia enter into a woman's pubic hole which then ejects their cement". $\left.{ }^{*}\right)$

The rise of children who experience rape will result in a prolonged psychological impact such as a child experiencing stress and emotional disturbance. Even, cases of rape or sexual 
violence against children need to be taken seriously, including in terms of prevention, repression and punishment of the perpetrators. Even this must act on all elements of the government, law enforcement, media and society. According to Arist Merdeka Sirait, there are four factors causing a child to experience rape:

a. First, children who have the potential to experience victims of crime. In this case, children tend to be coward, dressed, hyperactive, lack of parental supervision.

b. Second, children who like watching video games, television, movies

c. Third, Lack of supervision and protection of adults / parents against children. It is because the children are often left alone in playing, with a maid, uncle or stepfather.

d. Fourth, the child often becomes a victim because the child is often hugged, held on his lap, kissed but the child does not dare to fight.

Meanwhile, according to Khofifah Indraparawangsa, Minister of Social Affairs of the Republic of Indonesia "the cause of children experience sexual violence or rape are the easiness on accessing pronographic content on internet, buying and consume drugs and alcohol"(9)

Based on the motives of the perpetrators who committed sexual assault or crime can be grouped:

1. Seductive Rape

It is a rape that occurs because the perpetrator feels aroused lust and this is very subjective. This type of rape is common between perpetrators and victims who have known each other, such as rape by a boyfriend, friend or person near the victim's environment.

2. Sadistic Rape

This type of rape is carried out sadistically. In raping, sadistic perpetrators get sexual satisfaction not because of sexual intercourse or sexual intercourse, but because of the violence committed on a woman's body especially in her genetical organs.

3. Anger Rape

The victim raped by perpetrators as an expression of anger. This type of rape is usually accompanied by physical brutality. Sexual satisfaction is not the main goal but the act is only as an outlet for anger.

4. Domination Rape

This type rape is motivated by the perpetrators' desire to show the perpetrators' dominance against the victims. So in this case the perpetrator wants to show that he can control the victim in sexual matters, and this is often happen in the scope of the employer to the maid.

5. Exploitation Rape

This type of rape occurs a lot due to the dependence of victims on the perpetrators both because of economic and social factors. In this type of rape, the perpetrator does not use violence, but the perpetrator can threaten the victim so that the victim cannot reject the perpetrator's actions. Like between employers and laborers or subordinates." (10)

Sexual violence or rape the underage children is a criminal act. Therefore, the perpetrators need to be given strict actions in the form of criminal sanctions. Hopefully, the Government sees the high level of sexual crime against children and encourages the Government to impose heavier criminal sanctions. Since underage children who become victim of rape or sexual crimes will experience "Post Traumatic Stress Disorder", namely anxiety disorders, emotional insecurities, and flashbacks of a very painful experience after physical and emotional stress that goes beyond the limits of ordinary people. This is an anxiety disorder that can threaten the lives of victims. The impact of the anxiety disorder can be a psychically disorder such as depression, a ruptured blood membrane, bruises, genitals, irritation of the urine, venereal disease, HIV, unwanted pregnancies, avoided by the environment, feel everyone talk about her ".(11) 
Regarded to these basics, it is necessary to provide criminal sanctions for perpetrators of sexual violence or percussion against children:

a. "Article 81 of Law No. 35 of 2014:

(1) Every person who violates the provisions referred to in Article 76D shall be sentenced to a minimum of 5 years imprisonment and a maximum of 15 years and a maximum fine of Rp. 5,000,000,000

(2) The criminal provisions referred to in paragraph (1) also apply to anyone who deliberately commits deception, a series of lies or persuades a child to have sex with him or another person.

(3) In the event that the offense referred to in paragraph (1) is carried out by parents, guardians, child caregivers, educators or education personnel, then the speech will be added $1 / 3$ (one third) of criminal threats as referred to in paragraph (1) ".

b. "Article 82 of Law No. 35 of 2014:

(1) Every person who violates the provisions referred to in Article 76E shall be sentenced to a minimum of 5 years imprisonment and a maximum of 15 years and a maximum fine of Rp. 5,000,000,000

(2) In the event that the offense referred to in paragraph (1) is carried out by a parent, guardian, child caregiver, educator or educational staff, then the speech will be added $1 / 3$ (one third) of the criminal threat as referred to in paragraph (1)".

The evidence of the Government's seriousness in handling sexual crimes against children in 2016 is that the Government promulgated Law No. 17 of 2016 which is concerning Second Amendment to Law No. 23 of 2002 concerning Protection of Children which is applying heavier criminal sanctions. "If the victim sustains serious injuries, mental disorders, infectious diseases, disruption or loss of reproductive function, the victim dies the perpetrator can be sentenced to death, life time, imprisonment of at least 10 years, and a maximum of 20 years. In addition, the offender can be given an additional criminal form of the announcement of the judge's decision. If you have been convicted and the perpetrator repeats it can be given additional crimes of chemical castration and the installation of electronic detective devices (Article 81 and Article 82 of Law No. 17 of 2016)".

\section{Conclusion}

Based on this research, the Sanctions must be given for perpetrators of sexual crimes against children as it is stated in Article 82, Article 81 of Law No. 35 of 2014 and Announcement of Judge Decisions, Installation of chemical castings and electronic detection devices in accordance with Law No. 17 of 2016.

\section{References}

1. S. Harahap, JMH, Legal Protection of Children Victims of Sexual Crimes in Progressive Legal Perspectives, 23 (2016)

2. D. Setyawan. 2017. Tahun 2017, KPAI Temukan 116 Kasus Kekerasan Seksual Terhadap Anak. Diakses pada 5 Desember 2017, dari: http://www.kpai.go.id/berita/tahun-2017-kpai-temukan-116-kasus-kekerasanseksual-terhadap-anak

3. S. Soekanto, Introduction to Legal Research (UI Presss, Jakarta, 2015)

4. D. Setyawan. 2014. Perlindungan Hukum Terhadap Anak Korban Kejahatan Perkosaan Dalam Pemberitaan Media Massa. Diakses pada 2 Agustus 2018, dari: 
http://www.kpai.go.id/artikel/perlindungan-hukum-terhadap-anak-korbankejahatan-perkosaan-dalam-pemberitaan-media-massa

5. Hariyanto, Impact of Socio-Psychology of Rape Victims Against Women, Center for Women's Studies, (Universitas Gajah Mada, Jogyakarta, 1997)

6. Poerwadarminta, Indonesia Dictionary, Jakarta (1984)

7. M. Suparman, Sexual Harassment, (Faculty of Law Universitas Islam Indonesia, Yogyakarta, 1997)

8. R. Sugandhi, The Penal Code and its Explanation, (Surabaya, Usaha Nasional, 2003)

9. Harian Analisa. 2016. Mensos: 3 Faktor Penyebab Terjadi Kekerasan Seksual. Diakses pada 4 Juni 2018, dari: http://news.analisadaily.com/read/mensos-3-faktorpenyebab-terjadi-kekerasan-seksual/238649/2016/05/03

10. W. Abdul dan I. Muhammad, Protection of Victims of Sexual Violence, Advocacy for Women's Rights, (Refika Ditama, Bandung, 2011)

11. I. Noviana, SI, Sexual Violence Against Children: Impact and Handling of Socio, 01 (2015) 